\title{
Acclimation with humic acids enhances maize and tomato tolerance to salinity
}

\author{
Aline Costa Souza', Daniel Basílio Zandonadi², Mirella Pupo Santos², Natália Oliveira Aguiar Canellas' , \\ Cleiton de Paula Soares ${ }^{1}$, Luiz Eduardo Souza da Silva Irineu' ', Carlos Eduardo de Rezende ${ }^{3}$, Riccardo Spaccini", \\ Alessandro Piccolo ${ }^{4}$, Fabio Lopes Olivares ${ }^{1}$ and Luciano Pasqualoto Canellas ${ }^{1 *}$ (B)
}

\begin{abstract}
Background: Salinity is one of the major environmental threats to agriculture, limiting plant growth and reducing crop yield. The use of humic substances to alleviate salt stress in plants is well reported, but the mechanisms remain unclear. This work aimed to apply humic acids on seedlings to acclimate plants to tolerate further salt stress exposition as a pre-treatment.
\end{abstract}

Materials and methods: Two independent experiments with mono (maize) and dicot (tomato) seedlings were carried out. Maize was primed by humic acids $(4 \mathrm{mM} \mathrm{C}$ ) and further submitted to moderate salinity exposition ( $60 \mathrm{mM}$ $\mathrm{NaCl}$ ). The acclimation period of maize seedlings was characterized by ion balance and transcriptomic analysis of salt response genes. The tomato seedlings were also primed by humic acids ( $4 \mathrm{mM} \mathrm{C}$ ) and exposed further to salinity $(200 \mathrm{mM} \mathrm{NaCl})$, and we measured only physiological aspect, including the activity of plasma membrane proton pumps and net photosynthesis rate.

Results: Seedlings primed by humic acids minimized the salinity stress by changing ion balance, promoting plasma membrane proton pumps activity and enhancing photosynthesis rate and plant growth. We showed for the first time that maize seedlings treated with humic acids had a high transcription level of salt responsive genes and transcription factors even before the salt exposition.

Conclusion: Humic acids previously activate cellular and molecular salt defence machinery, anticipating the response and reducing salinity stress. This is a key knowledge to manipulate manufactured biostimulants based on humic substances towards a maximized crop protection.

Keywords: Humic substances, Salinity, Abiotic stress, Stress alleviation, Plant tolerance, Biostimulants, Plant acclimation

\section{Introduction}

The salinity of agricultural lands increased worldwide due to the intensity of modern industrial agriculture, limiting plant growth and reducing crop yield [1]. High salt concentration disturbs intracellular ion homeostasis

\footnotetext{
*Correspondence: canellas@uenf.br

${ }^{1}$ Núcleo de Desenvolvimento de Insumos Biológicos Para Agricultura (NUDIBA), UENF-Universidade Estadual Do Norte Fluminense Darcy Ribeiro, Av. Alberto Lamego 2000, Campos dos Goytacazes, Rio de Janeiro 28013-602, Brazil

Full list of author information is available at the end of the article
}

and causes oxidative stress in plant cells [2]. Increasing salt tolerance of crop plants is a key point for sustainable agriculture.

Different efforts have been made to increase salt tolerance, including current plant breeding and transposition of genes from halophyte to crop plants [1]. The salt-acclimation process is one of the most promising agronomical approaches [3]. Pandolfy et al. [3] reported that shortterm exposure of the glycophyte species to a low salt concentration activates a set of physiological adjustments enabling the plants to withstand further severe saline 
conditions. According to these authors, the acclimation to external environmental changes can occur in plants due to internal adjustments within tissues and cells, enabling plant metabolism to proceed under these somewhat altered conditions.

We try to adapt this concept using humic acids (HA) as an agent to induce plant acclimation, since their ability to mitigate the negative effects caused by salinity in different plants has been widely reported [4-6]. HA are one of the most popular categories of biostimulants, defined as materials that contain one or more substances and/or microorganisms able to stimulate nutrient uptake and use efficiency by plants, increase plant tolerance to abiotic stress, and improve crop quality when applied in small amounts [7]. The enhancement of peroxidase activity, reduction of $\mathrm{H}_{2} \mathrm{O}_{2}$ concentration, and increased cell proline levels in seedlings treated with HA were previously reported [8]. All of these responses are classical physiological adaptation against abiotic stress. Moreover, maize seedlings acclimated by HA better withstand further stress exposition, including osmotic stress, heavy metal toxicity and high concentration of HA itself [9].

The most described plant physiologic adjustment induced by $\mathrm{HA}$ is the plasma membrane (PM) proton pump stimulation [10], modulating the cellular electrical environment and ion fluxes $[11,12]$. It has also been reported that HA promoted the activity of HKT1 transporters helping Arabidopsis to survive salt effects [13]. The HA application may also induce changes in ion balance and other physiological adjustments, such as the accumulation of osmoprotectant compounds or the enzymatic and non-enzymatic scavenge activity [6]. The results considering genetic response against salinity induced by HA are scarce [13].

The objective of the present study was to evaluate the response mechanisms of maize and tomato seedlings to salinity induced by humic acids.

\section{Material and methods Humic acids (HA)}

A sugarcane filter cake vermicompost was used to extract HA using standard methods and characterized as reported elsewhere $[9,31]$.

\section{Maize acclimation}

Maize (Zea mays var. DEKALB 177) seeds were surface sterilized by soaking in $0.5 \%(\mathrm{v} / \mathrm{v}) \mathrm{NaClO}$ for $30 \mathrm{~min}$, followed by rinsing and then soaking in water for $6 \mathrm{~h}$. Afterwards, the seeds were sown in $2 \mathrm{~L}$ pot filled with sand:vermiculite substrate (2:1, v:v) and daily irrigated with distilled water. After germination, seedlings were thinned, leaving only two seedlings per pot. The seedlings were grown in a greenhouse and irrigated daily with one-quarter strength of Furlani's nutrient solution for 2 weeks. The composition of this nutrient solution was $\left(\mu \mathrm{mol} \mathrm{L}^{-1}\right)$ : $3.527 \mathrm{Ca} ; 2.310 \mathrm{~K} ; 855 \mathrm{Mg} ; 45 \mathrm{P} ; 587 \mathrm{~S} ; 25$ B; $77 \mathrm{Fe}$; $9.1 \mathrm{Mn}$; $0.63 \mathrm{Cu}$; $0.83 \mathrm{Mo} ; 2.29 \mathrm{Zn} ; 1.74 \mathrm{Na}$; and 75 EDTA with the $N$ content adjusted to a low concentration $\left(100 \mu \mathrm{mol} \mathrm{L}{ }^{-1} \mathrm{NO}_{3}{ }^{-}+\mathrm{NH}_{4}{ }^{+}\right)$. After this time, the maize seedlings were exposed or not (control) to $4 \mathrm{mmol}$ $\mathrm{L}^{-1} \mathrm{C}$ of HA for 5 days. After this time, the maize seedlings were exposed or not to moderate salt concentration $\left(\mathrm{NaCl} 60 \mathrm{mmol} \mathrm{L}^{-1}\right)$ for additional 3 days. Before the salinity exposition, the plants were harvested before and after the salinity exposition to evaluate the ion balance on root and leaf tissues and the differential transcription level of target genes induced by HA on roots.

After drying, leaf and root tissues of the maize seedlings were ground in a Wiley grinder. Then the powder was submitted to digestion using microwave energy with aqua regia in a closed vessel, and $\mathrm{Na}^{+}, \mathrm{K}^{+}, \mathrm{Ca}^{2+}$, and $\mathrm{Mg}^{2+}$ were analysed using ICP-AES atomic absorption spectroscopy (Bruker, Germany). For RNA extraction, $100 \mathrm{mg}$ fresh weight of control roots and HA-treated roots were macerated in liquid nitrogen. The total RNA of the samples (three biological replicates per treatment) was extracted with the RNeasy ${ }^{\circledR}$ Plant Mini Kit (QIAGEN), according to the manufacturer's instructions. Total RNA was quantified using the NanoDrop ${ }^{\mathrm{TM}} 2000$ (NanoDrop $^{\mathrm{TM}}$ Technologies, Wilmington, DE, EUA). The RNA was eluted in DEPC-treated water (total amount of 4-10 $\mu \mathrm{g}$ RNA) digested with DNAse and depleted of ribosomal RNA using the GOTAQ ${ }^{\circledR}$ 1-STEP RT-QPCR (PROMEGA). Subsequently, a $1 \%$ free RNAse agarose gel was made to analyse the integrity of the RNA extracted. Sequencing libraries were prepared using the Whole Transcriptome Analysis kit (Applied Biosystems) according to the manufacturer's protocol. Libraries were sequenced on the Illumina platform by LacTad Company (Brazil). To perform bioinformatics analysis of the sequences obtained by RNA-Seq, the reads obtained from the RNA-Seq were analysed to identify ribosomal RNA (rRNA) sequences in two steps: 1-rRNA sequences of Zea mays were downloaded from NCBI, and an index file of rRNA was created using NovoAlign v3.06.05. (http://www.novocraft.com/products/novoa lign/). Then, reads were mapped on an index file using NovoAlign. 2-all fastq files were converted into Fasta, and BLASTN Analysis was performed against downloaded rRNA sequences. Identified rRNA sequences were removed, and reads were cleaned.

Furthermore, the quality of all reads was accessed by running the FastQC software, and high-quality cleaned reads were aligned on $Z$. mays genome using NovoAlign. Gene expression levels were normalized as reads per kilobase of transcript per million mapped reads (RPKM). The 
genes with differences of at least onefold change along with adjusted $p$ value (FDR) $\leq 0.05$ were considered to be significantly differentially expressed genes. Functional classification analysis was executed with MapMan version 3.6.0RC1 (https://mapman.gabipd.org/).

To confirm the transcriptomic analyses, we performed additional experiments using Real-Time quantitative PCR (RT-qPCR) to validate candidates differentially expressed genes. Maize seedlings were grown in the same conditions as previous experiments (control and HA) but with an additional treatment including salt exposition during the acclimation period $\left(60 \mathrm{mmol} \mathrm{L}^{-1} \mathrm{NaCl}\right)$ to evaluate the specific salinity gene response induced by $\mathrm{NaCl}$ exposition. The treatments (control, $\mathrm{HA}, \mathrm{NaCl}$ ) were replicated three times (three individual pots per treatment containing four maize seedlings with the same $5 \mathrm{~cm}$ initial main root length) in a completely randomized statistical design. Three seedlings per pot were used for the analysis of RT-qPCR. The total RNA was isolated checked for integrity as described before. The RT-qPCR was conducted using $7.5 \mu \mathrm{L}$ of Fast SYBR $^{\mathrm{TM}}$ Green Master Mix in StepOnePlus ${ }^{\mathrm{TM}}$ Real-Time PCR System (Applied Biosystems ${ }^{\text {TM }}$, CA, EUA). The target genes (specific salt response: SOS3; Kinase protein: SnRk2.2; transcription factors: bZip17 and NAC66) and primers description (forward and reverse sequence) were shown in Additional file 1: Table S1. Primer sets were designed using Primer Express 3.0 (Applied Biosystems, USA). Total RNA $(5 \mu \mathrm{g})$ was treated with DNAase I (Invitrogen) and used for cDNA synthesis with the Superscript III First-strand synthesis kit (Invitrogen). The PCR consisted of 7.5 $\mu \mathrm{L}$ of SYBR Green PCR Master Mix, at concentrations $500 \mathrm{nmol} \mathrm{L}^{-1}$ of forward and reverse primers and $1.0 \mu \mathrm{L}$ of 16 -fold-diluted cDNA template in a total volume of $15 \mu \mathrm{L}$. Cycling was performed using the default conditions of the 7500 Software v 2.0.5: $2 \mathrm{~min}$ at $95^{\circ} \mathrm{C}$, followed by 40 cycles of $20 \mathrm{~s}$ at $95{ }^{\circ} \mathrm{C}$ and $30 \mathrm{~s}$ at $60{ }^{\circ} \mathrm{C}$. All RT-qPCR assays were carried out using three technical replicates and with a non-template control. The genes $\alpha$-Tubulin $(\alpha$-Tub) and Tubulin $\beta$-chain $(\beta-T u b)$ were used as normalizing genes. The relative gene expression was determined using the qBase v.1.3.5 [14].

\section{Tomato acclimation}

Tomato (Solanum lycopersicum cv. Rheinlands Ruhm) seeds were germinated for 7 days in vermiculite, and the seedlings were transferred to a hydroponic system containing one-half-strength Hoagland solution either without or with $4 \mathrm{mM} \mathrm{C} \mathrm{L}{ }^{-1}$ of HA. The nutrient solution was replaced weekly, while distilled water (or HA with distilled water) was replenished daily. Plants were grown in a chamber at $25{ }^{\circ} \mathrm{C}$ (day) and $22{ }^{\circ} \mathrm{C}$ (night).
After 5 weeks of pre-treatment, plants underwent additional 7 days to four different treatments: $1.4 \mathrm{mM} \mathrm{C}$ $\mathrm{L}^{-1}$ of $\mathrm{HA}$, 2. $200 \mathrm{mmol} \mathrm{L}^{-1} \mathrm{NaCl}$, 3. HA plus $\mathrm{NaCl}$, and 4. Control (half-strength Hoagland's only). Each treatment consisted of ten plants in a completely randomized design. These experiments were repeated three times. Tomato net photosynthesis $(A)$, stomatal conductance to water vapour $\left(\mathrm{g}_{\mathrm{s}}\right)$ and transpiration (Tr) were obtained under steady-state photosynthetic conditions using a portable open-system infrared gas analyzer (Li-Cor 6400; LiCor, Lincoln, NE, USA) with external $\mathrm{CO}_{2}$ supply. The chlorophyll $a$ fluorescence parameter was measured in the second pair of tomato leaves (fully expanded) by a miniaturized pulse-amplitude modulation fluorometer, Mini-PAM $(\mathrm{H}$. Walz, Effeltrich, Germany), as previously described [15]. Potential quantum yield $\left(F_{v} / F_{m}\right)$ of photosystem II (PSII) was measured during the day after darkening the leaves for $30 \mathrm{~min} . F_{v}$ is the maximum variable fluorescence, and $F_{m}$ is the maximum fluorescence of the darkadapted leaf under a light saturating flash $\left(F_{v}=F_{m}-F_{0}\right.$ where $F_{0}$ is the ground fluorescence of the dark-adapted leaves). The apparent maximal electron transport rate (ETRmax) and effective quantum yield of PSII $\left(\Delta F / F^{\prime}{ }_{m}\right)$ were obtained from the light-response curves. $\Delta F / F^{\prime}{ }_{m}$ was calculated as $F_{m}^{\prime}-F / F_{m}^{\prime}$, where $F$ is the fluorescence yield of the light-adapted sample and $F_{m}^{\prime}$ is the maximum fluorescence obtained when a light pulse of $800 \mathrm{~ms}$ duration (intensity ca. $3000 \mu \mathrm{mol} \mathrm{m}{ }^{-2} \mathrm{~s}^{-1}$ ) is superimposed on the general environmental light levels. The determination of photosynthetic pigments was done after the purification of chlorophylls and carotenoids. Briefly, $100 \mathrm{mg}$ of leaf fresh weight was added to $5 \mathrm{~mL}$ dimethyl sulphoxide in glass tubes and kept protected from light for $72 \mathrm{~h}$ until the chlorophyll $a$ and $b$ and total carotenoid were determined by spectrophotometry as previously described [16]. Plasma membrane $(\mathrm{PM}) \mathrm{H}^{+}$-ATPase activity was measured in root vesicles preparation according to Canellas et al. [17]. The activity of nitrate reductase (NR) was determined using $0.5 \mathrm{~g}$ of root intact tissues cut into $2 \times 2 \mathrm{~mm}$ pieces and incubated for $30 \mathrm{~min}$ after vacuum infiltration in $5 \mathrm{~mL}$ of a reaction mixture containing $50 \mathrm{mM}$ phosphate buffer (pH 7.5), $50 \mathrm{mM} \mathrm{KNO}_{3}$, and $1 \%(\mathrm{v} / \mathrm{v})$ propanol. Nitrate reductase activity was estimated by the amount of $\mathrm{NO}_{2}$ released.

Two hundred and twelve into the incubation solution, measured in a spectrophotometer at $540 \mathrm{~nm}$ [18]. Membrane integrity was determined using electrical conductivity protocol, and lipid peroxidation was determined by measuring the amount of malondialdehyde (MDA) produced by thiobarbituric reaction according to Santos et al. [18]. 


\section{Results}

The HA isolated from vermicompost was characterized in previous studies (XX), and the carbon content (46\%) was used to prepare HA suspension to plant treatments. The main chemical characteristic of HA is the presence of an intense and sharp peak at $56 \mathrm{ppm}$ and $174 \mathrm{ppm}$ on $\mathrm{CP} / \mathrm{MAS}{ }^{13} \mathrm{C}$ NMR spectrum assigned to methoxy and
O-alkyl groups from cellulose, hemicellulose, and lignin structures and carboxyl groups, respectively [18].

\section{Maize seedlings at acclimation period}

The maize seedlings primed by $4 \mathrm{mM} \mathrm{C}$ of HA increased both the shoot and root fresh weight compared to control (Fig. 1A, B). After moderate salt exposition $(60 \mathrm{mM}$

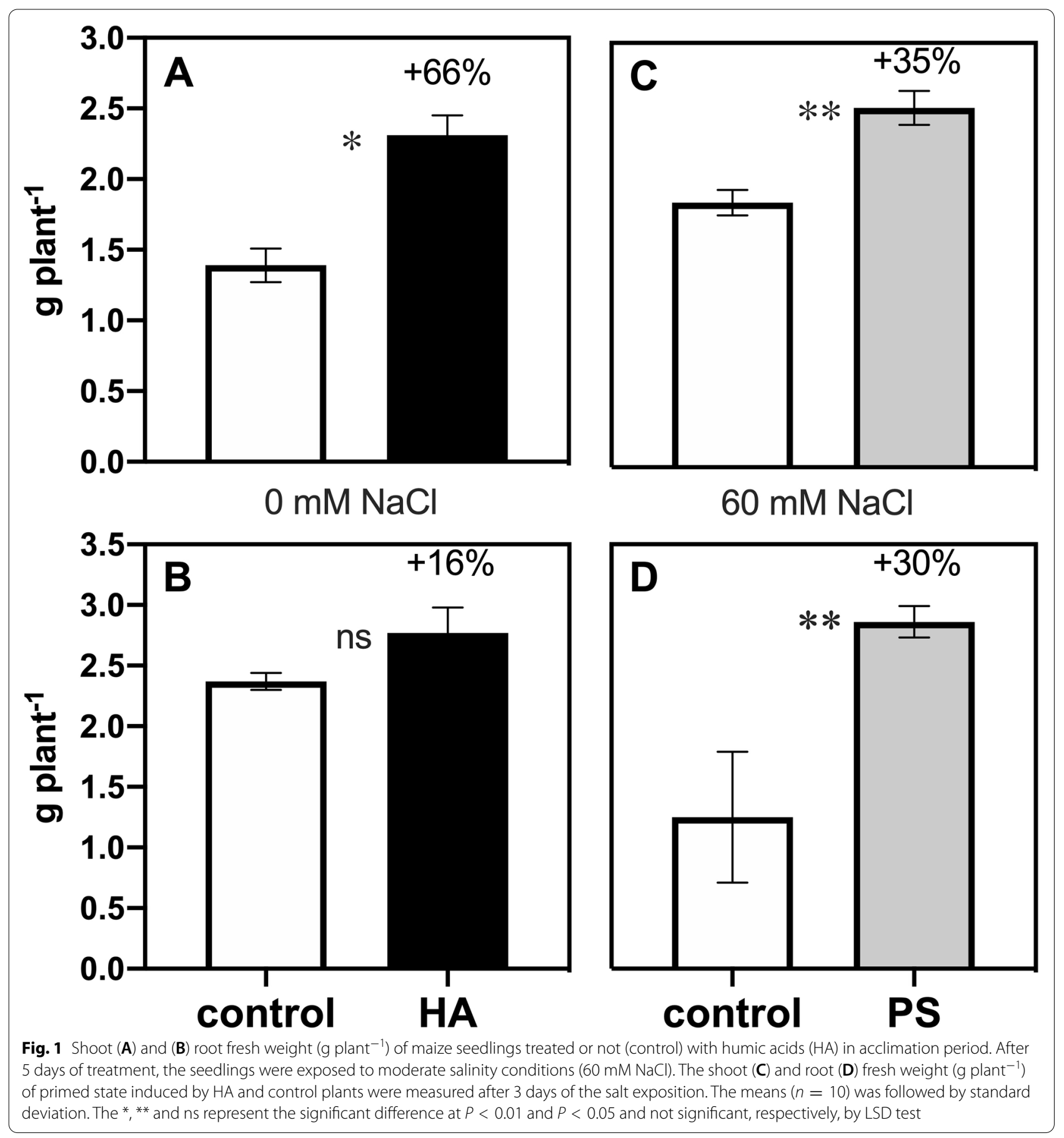


$\mathrm{NaCl}$ ), the seedlings previously treated with HA sustained the significant shoot weight difference observed in the acclimation period regarding control (Fig. 1C). In addition, seedlings treated with HA increased the root fresh weight compared to control plants submitted to salt stress (Fig. 1D).

The $\mathrm{Na}^{+}, \mathrm{K}^{+}$and $\mathrm{Ca}^{2+}$ content and $\mathrm{K}^{+} / \mathrm{Na}^{+}$and $\mathrm{Na}^{+} /$ $\left(\mathrm{Ca}^{2+}+\mathrm{Mg}^{2+}\right)$ ratio of root maize seedlings are shown in Fig. 2. The maize seedlings primed by HA enhanced $\mathrm{K}^{+}$and $\mathrm{Ca}^{2+}$ content and decreased $\mathrm{Na}^{+}$uptake. When maize seedlings primed by humic acids were exposed to salinity, no differences were observed in root tissues for both treatments (control vs PS) regarding $\mathrm{Na}^{+}$content. However, the $\mathrm{K}^{+}$content increased in primed seedlings, decreasing the $\mathrm{Na}^{+} / \mathrm{K}^{+}$ratio and consequently changing the ion balance in root tissues. In the first phase of the experiment, the $\mathrm{Na}^{+} / \mathrm{Ca}^{2+}+\mathrm{Mg}^{2+}$ ratio decreased, since the $\mathrm{HA}$ treated seedlings also had a larger $\mathrm{Ca}^{2+}$ content in root tissues than in control. The difference in $\mathrm{Ca}^{2+}$ content and $\mathrm{Na}^{+} / \mathrm{Ca}^{2+}+\mathrm{Mg}^{2+}$ ratio was maintained when seedlings were subjected to saline stress, but to a lesser extent, probably due to a large $\mathrm{Na}^{+}$concentration in the medium.

We directed the transcriptome analysis for significant differential expression (in respect to control) of genes related to osmotic stress (drought/salinity) in the acclimation period. The produced maps revealed 34 genes in a high level of transcription in maize roots seedlings treated with HA (Fig. 3). Out of these maps, 12 were up-regulated and 22 down-regulated. Additional file 1: Table S2 describes the main function of each of the genes. Nine of these genes were related to $\mathrm{Na}^{+}$detoxification by the SOS family. The sodium proton exchanger SOS1 showed a greater transcription level in HA seedlings, while one sodium/calcium exchanger was downregulated. However, six SOS3 interacting proteins were found at a high transcription level, half upregulated, and half downregulated (Fig. 3). The transcript GRMZM2G044038 (SOS3.1; Fig. 3) was further used for RT-qPCR because of its higher transcription level.

We conducted an additional experiment to verify the quantitative differential expression by RT-qPCR of some specific saline response genes, transcription factors (TF) and kinases responsible for the cell signalling amplification (Figs. 4, 5). The Zea mays Salt Overlay Sensitive-3 (ZmSOS3) transcription level was significantly larger than control, including that for maize seedlings treated with $60 \mathrm{mM}$ of $\mathrm{NaCl}$ (Fig. 4).

Also, the transcriptional level of ZmNAC66 (the acronyms is a consequence of three different proteins: No apical meristem; Arabidopsis ATAF1/2 and Cupshaped cotyledon) and basic region/leucine zipper motif (ZmbZIP17) transcription factors, were found lager
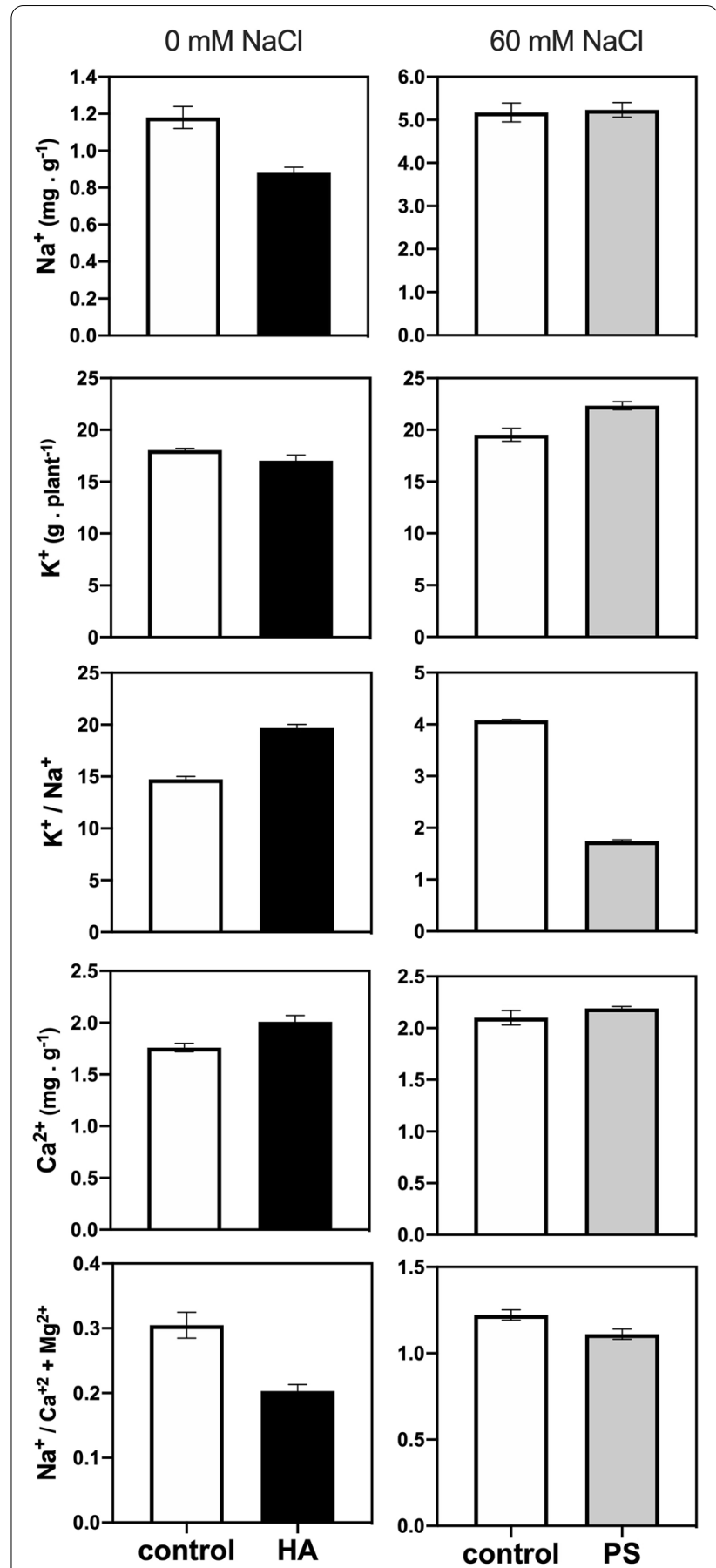

Fig. 2 lon content $\left(\mathrm{Na}^{+}, \mathrm{K}^{+}, \mathrm{Ca}^{2+}\right)$ and ion ratio $\left(\mathrm{Na}^{+} / \mathrm{K}^{+}, \mathrm{Na}^{+} /\right.$ $\mathrm{Ca}^{2+}+\mathrm{Mg}^{2+}$ ) of maize seedlings root tissues in the first phase of experiment acclimation period (control $\times$ humic acids, HA) and under moderate salt exposition (control $\times$ primed state, PS). The means ( $n=4$ ) was followed by the standard deviation in $\mathrm{mg} \mathrm{g}^{-1}$ of root fresh weight 


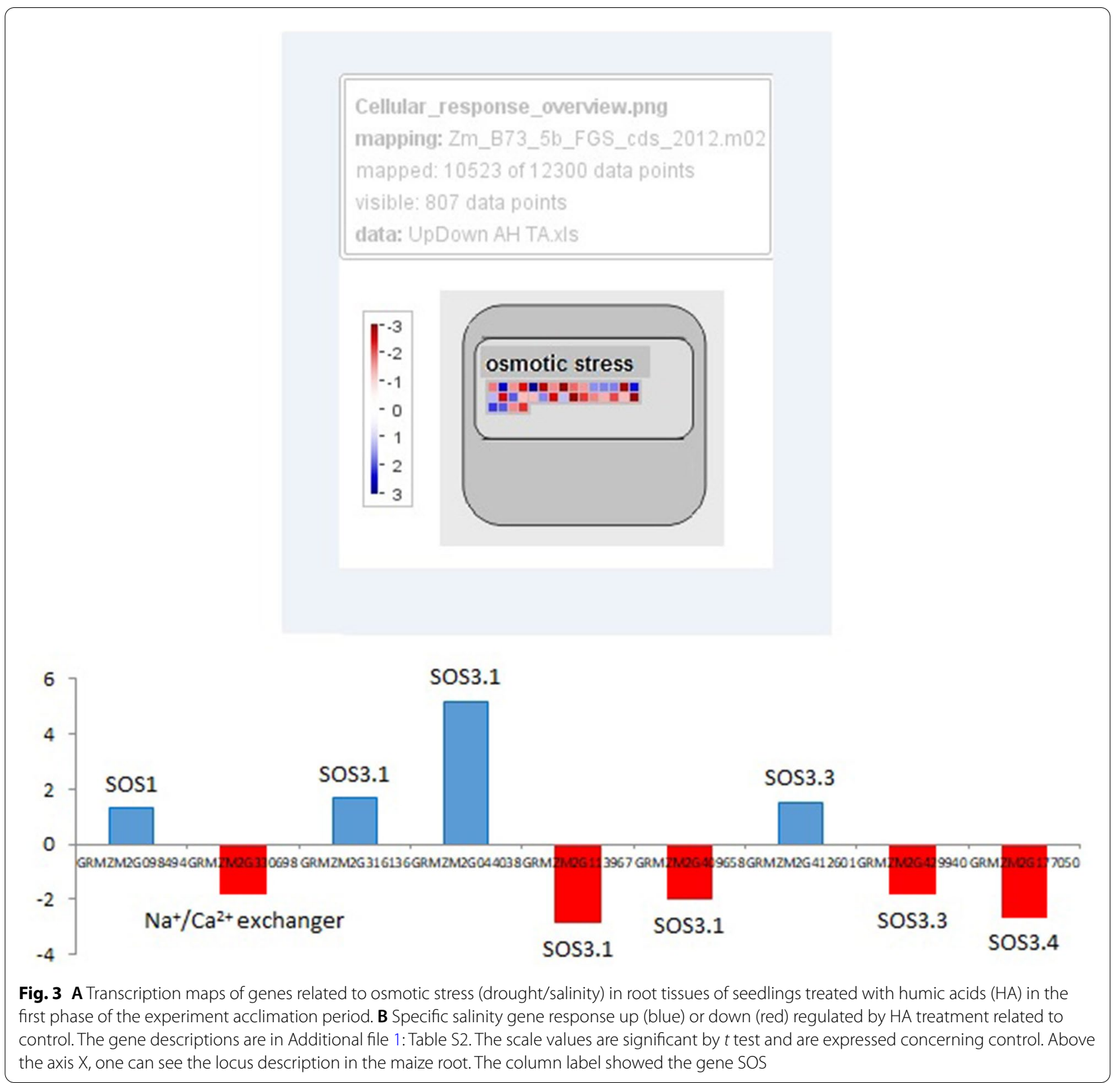

than control in primed seedlings (Fig. 5), but the transcriptional level of ZmNAC66 was similar in the maize seedlings treated with $\mathrm{HA}$ or $\mathrm{NaCl}$ (Fig. 5A), whereas the ZmbZIP17 resulted greater for $60 \mathrm{mM} \mathrm{NaCl}$ than for $4 \mathrm{mM} \mathrm{C}$ of HA (Fig. 5B). The transcriptional level of genes that codify protein kinases SnRK1 [Sucrose Nonfermenting1 (SNF)-related kinase1] and SnRK2.2 is also shown in Fig. 5. Both kinases were up-regulated in the same level by $\mathrm{HA}$ and $\mathrm{NaCl}$, and in both treatments, the transcriptional level was significantly larger than control (Fig. 5C, D).

\section{Tomato physiological adjustment}

The inhibition of net photosynthesis rate reached 57\% in plants transferred for $200 \mathrm{mmol} \mathrm{L}^{-1}$ of the $\mathrm{NaCl}$ solution (Fig. 6), whereas the same rate remained unaltered in plants pre-treated with HA for 5 weeks. Similarly, the stomatal conductance was reduced by half in $\mathrm{NaCl}-$ stressed plants, while no decrease was observed in plants pre-treated with humic acids. The inhibition of transpiration rate was $37 \%$ in plants transferred for $\mathrm{NaCl}$, whereas pre-treatment with HA prevented the salt effect. While the potential quantum yield of PSII (Fv/Fm) decreased 


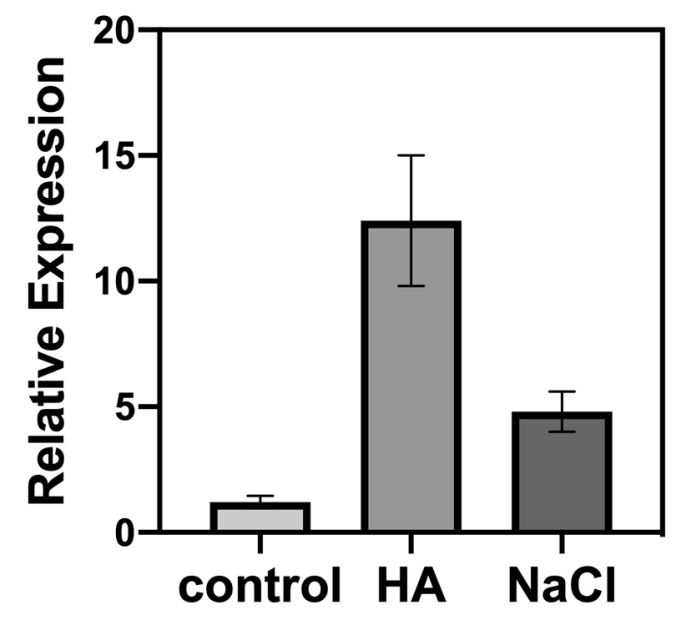

Fig. 4 Relative expression of the overly salt-sensitive gene (ZmSOS3) quantified by RT-qPCR in roots of maize seedlings treated or not (control) with $4 \mathrm{mM} \mathrm{C}$ of humic acids (HA) 4 and $60 \mathrm{mM} \mathrm{NaCl}$. The means $(n=4)$ was followed by the standard deviation

$80 \%$ in $\mathrm{NaCl}$-treated plants, pre-treatment with $\mathrm{HA}$ prevented the photochemical efficiency inhibition of $\mathrm{NaCl}$ compared to control plants (Fig. 6). Again, chlorophyll decreased by $45 \%$ in plants treated with $\mathrm{NaCl}$, whereas pre-treatment with HA reverted the salt effects (Fig. 6). Chlorophyll b and carotenoids were not significantly affected by treatments. Tomato primed by HA enhanced 60 and 25\% plasma membrane $\mathrm{H}^{+}$-ATPase and nitrate reductase activity, respectively, in pre-treated control plants (Fig. 7). Conversely, plants pre-treated with $\mathrm{HA}$ and transferred to $\mathrm{NaCl}$ presented an $80 \%$ larger $\mathrm{H}^{+}$-ATPase activity than control plants. On the other hand, control plants that were transferred to salt solutions presented a $65 \%$ larger stimulus of $\mathrm{H}^{+}$-ATPase activity than pristine control plants. Salt inhibited the nitrate reductase activity by $70 \%$, but pre-treatment with HA prevented this inhibition (Fig. 7).

Membrane integrity was $45 \%$ lesser in $\mathrm{NaCl}$ treatment than in control plants, whereas pre-treatment with humic acids partially prevented the $\mathrm{NaCl}$ effect (Fig. 7). Root malondialdehyde was more than two-fold larger in $\mathrm{NaCl}$ treatment than in control plants, but pre-treatment with humic acids prevented the salt effects (Fig. 7).

\section{Discussion}

The humic-like organic matter isolated from vermicomposts shows high biological activity, which acts as an effective plant growth promoter. The HA isolated from vermicompost enhanced root and shoot weight in maize and tomato seedlings.

We observed a clear decrease of salinity effects in maize seedlings primed by $\mathrm{HA}$, as measured by root and shoot fresh weight (Fig. 1). Seedlings primed by HA better withstood the subsequent exposure to salinity. The physiological adjustment involving ion balance regulation (Fig. 2) is one of the main osmotic stress alleviation mechanism. We report previously that maize seedlings treated with HA isolated from vermicompost enhance the PM H${ }^{+}$-ATPase activity $[17,19]$. However, besides physiological adaptation and in respect to root control seedlings, the analysis of significant genes transcription level showed the presence of 34 genes linked to osmotic stress (drought and salinity) in primed seedlings under no salinity exposure (Fig. 3; Additional file 1: Table S2). Among these, 12 genes codify proteins/ enzymes that are specifically linked to the salinity stress response. Up to our knowledge, this is the first report showing that HA induces the expression of the main antiporter associated with salinity stress (SOS3 system; Fig. 4).

The underlined mechanism associated with SOS systems for salt alleviation is well described in literature, although Munns and Tester [2] indicated some pitfalls, including a lack of relationship between expression and gene function patterns. The purpose of this paper was not to discuss this mechanism but just to show how and why humic substances can trigger a specific salinity tolerance mechanism without the presence of salt stress (Additional file 1: Figure S2). The SOS signalling pathway is a classical signal pathway, which occurs when a plant is exposed to high $\mathrm{NaCl}$ levels and functions in plants as regulating osmotic homeostasis in response to salt stress [20]. In this pathway, $\mathrm{Na}+$-induced increase in the cytosolic calcium concentration $[\mathrm{Ca} 2+]$ cyt" and calcineurin $\mathrm{B}$-like $(\mathrm{CBL})$ protein, originally identified as SOS3, that subsequently interacts with a CBL-interacting protein kinase (CIPK24, originally identified as SOS2). The CBL4/CIPK24 (SOS3/SOS2) complex targets the plasma membrane via a myristoyl fatty acid chain covalently bound to CBL4/SOS3, thus enabling the phosphorylation and the activation of the membrane-bound $\mathrm{Na}^{+} / \mathrm{H}^{+}$antiporter, SOS1 [2]. This pathway was first reported by characterizing genes whose expression was overly sensitive to salt stress (SOS).

In this work, we observed an increase of the $\mathrm{Ca}^{2+}$ concentration in root tissues of maize seedlings treated with HA (Fig. 2). The $\left[\mathrm{Ca}^{2+}\right]$ cyt pulse induced by HA was previously demonstrated in rice seedlings using the ionselective vibrating probe system [11]. $\mathrm{Ca}^{2+}$ influxes in the root elongation zone following the activation of the PM H${ }^{+}$-ATPase and the $\mathrm{Ca}^{2+}$-dependent protein kinase (CDPK). The latter was coupled with an increased expression of the voltage-dependent OsTPC $1 \mathrm{Ca}^{2+}$ channels and two stress-responsive CDPK isoforms, such as OsCPK7 and OsCPK17. The $\mathrm{Na}^{+} / \mathrm{K}^{+}$ratio (Fig. 2), an established 

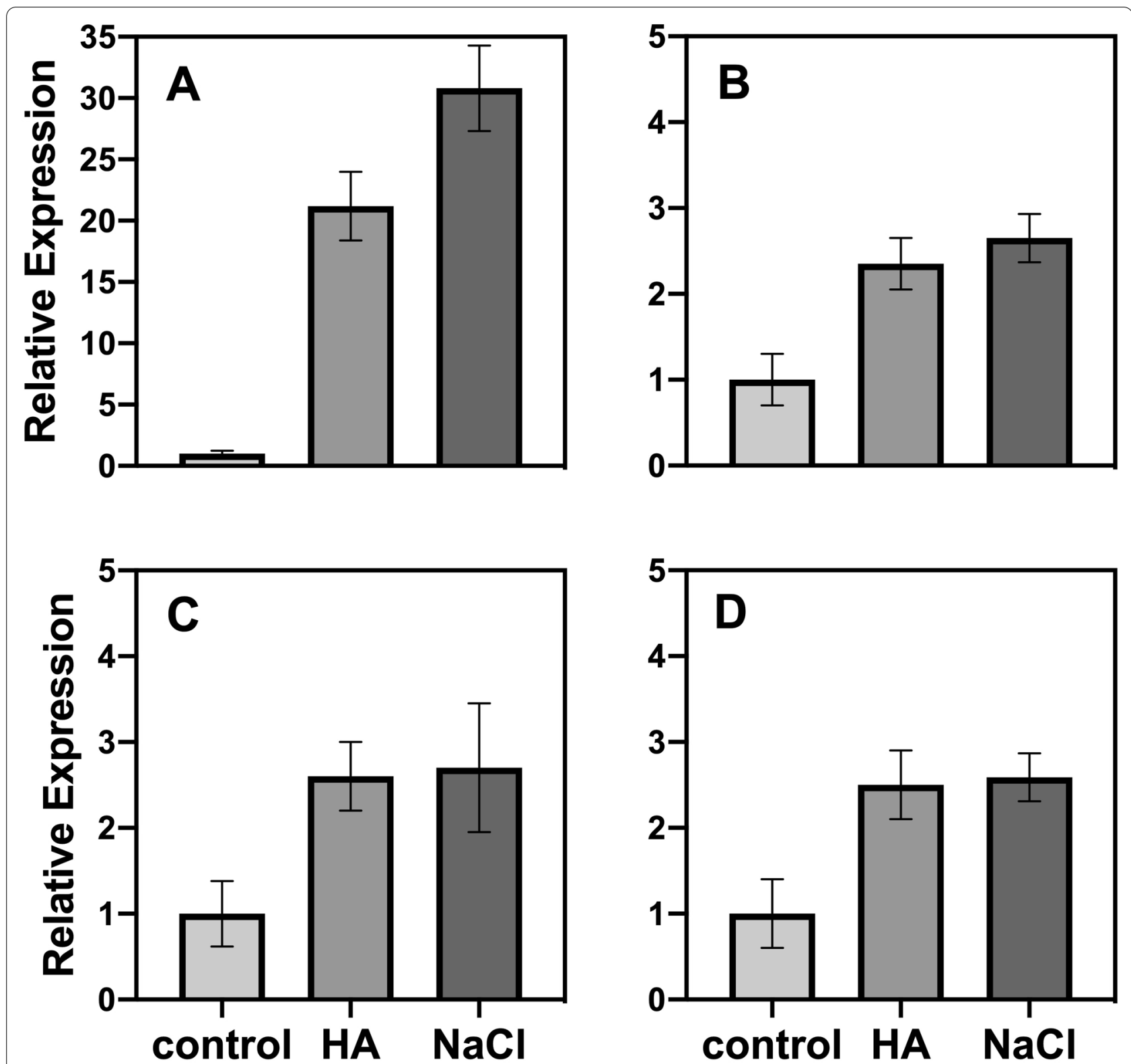

Fig. 5 Relative expression of genes quantified by RT-qPCR in maize roots. The maize seedlings were treated or not (control) with $4.0 \mathrm{mM} \mathrm{CL}{ }^{-1}$ humic acids (HA) or $60 \mathrm{mM} \mathrm{NaCl}$. T. A Basic leucine zipper (ZmbZIP17), B Protein highly conserved N-terminal (ZmNAC66), C SNF1-related protein kinase 1 (ZmSnRK1), D Protein serine/threonine kinase (ZmSnRK2.2). The means $(n=4)$ were followed by the standard deviation

indicator for salt stress response, decreased dramatically in the primed seedlings after exposure to salinity.

$\mathrm{Na}^{+} / \mathrm{K}^{+}$homeostasis in salt stress response was reviewed [21], highlighting the role of $\mathrm{H}^{+}$pumps, which generate the driving force for $\mathrm{K}^{+}$and $\mathrm{Na}^{+}$transport. The effect of humic substances on $\mathrm{H}^{+}$pumps is one of the main effects widely reported on ion uptake and root growth mechanism. Maize seedlings treated with different humic acids promoted concerted PM ( $\mathrm{H}^{+}$-ATPase) and tonoplast $\mathrm{H}^{+}$pumps (V-ATPase and $\mathrm{H}^{+}$-PPAse) activation [19]. The sensing and signalling mechanism of $\mathrm{Na}^{+}$stress was activated by HA in the nutrient solution with a relatively low electrical conductivity and deprived of $\mathrm{Na}^{+}$. This activation's downstream consequence was monitored by differential expression of key genes using real-time PCR technique. The Sucrose non-fermenting1-related protein kinase (SnRKs; Fig. 5) is a key component of the phosphorylation cascade related to the long-distance signalling control of net ion transport [22] that acts as a central integrator of stress (and energy level) 

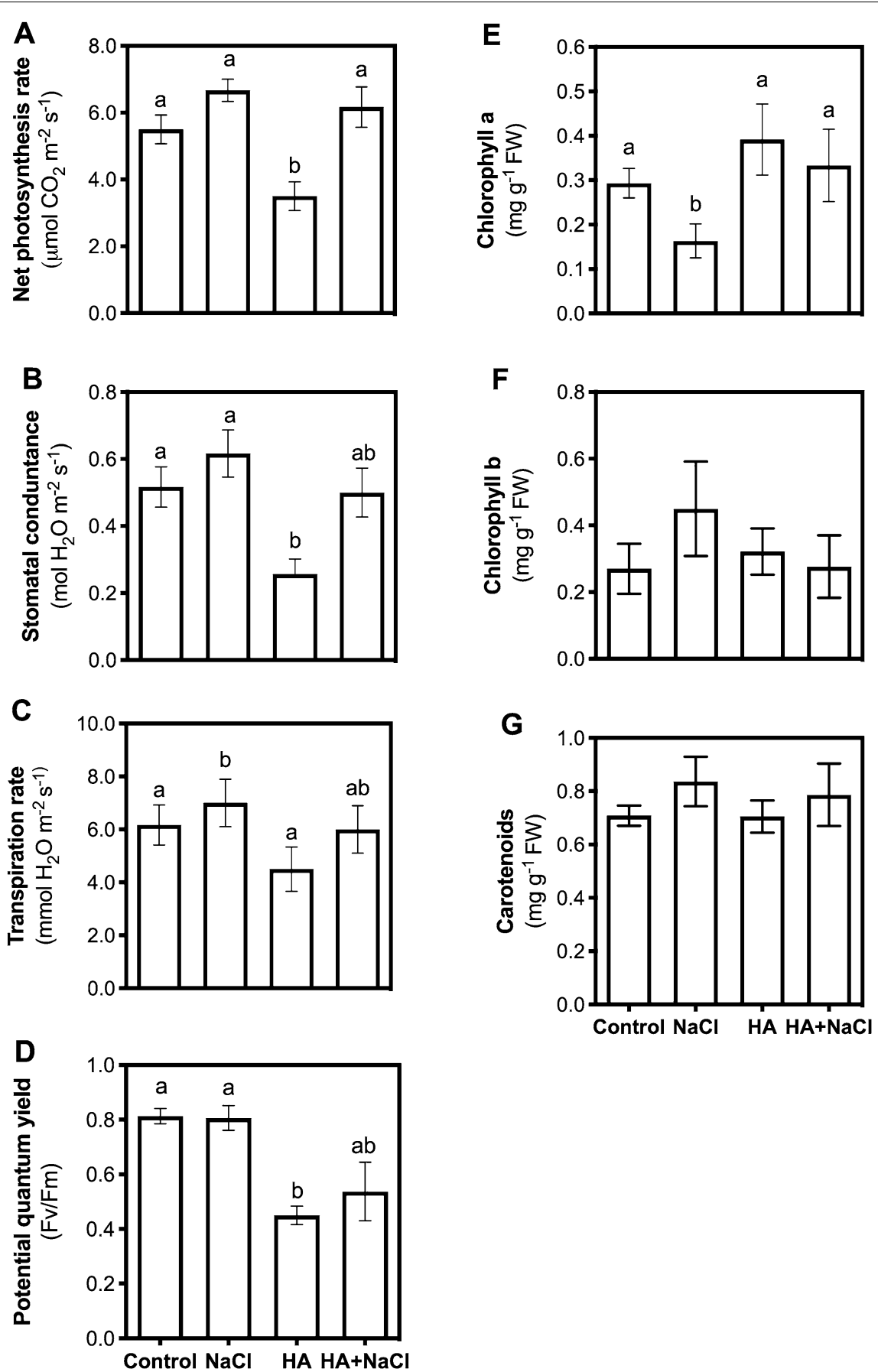

Fig. 6 Photosynthetic characterization of tomato plants. Data were obtained in 5-week-old plants with either control (1/2 strength Hoagland solution) or humic acids (control + 4 mM C HA) further treated for additional 7 days with $200 \mathrm{mM} \mathrm{NaCl}, 4 \mathrm{mM} \mathrm{C} \mathrm{HA} \mathrm{or} 200 \mathrm{mM} \mathrm{NaCl}$ plus $4 \mathrm{mM} \mathrm{C}$ HA. Values are presented as means $\pm S D(n=10)$. Different letters represent average values that were judged to be statistically different between 7-day treated plants $(P<0.05$, Tukey test). A Net of photosynthesis rate; $\mathbf{B}$ stomatal conductance; $\mathbf{C}$ transpiration rate; $\mathbf{D}$ quantum production yield; $\mathbf{F}$ total chlorophyll a content; $\mathbf{G}$ total chlorophyll b content; $\mathbf{H}$ total carotenoids content

and modulates the expression of more than 1000 genes through phosphorylation of various transcription factors [23]. We observed a great transcription level in both protein kinases SnRK1 and SnRK2.2 in primed seedlings, as well as in the transcription factors ZmNAC66 and ZmbZip17 (Fig. 5). 

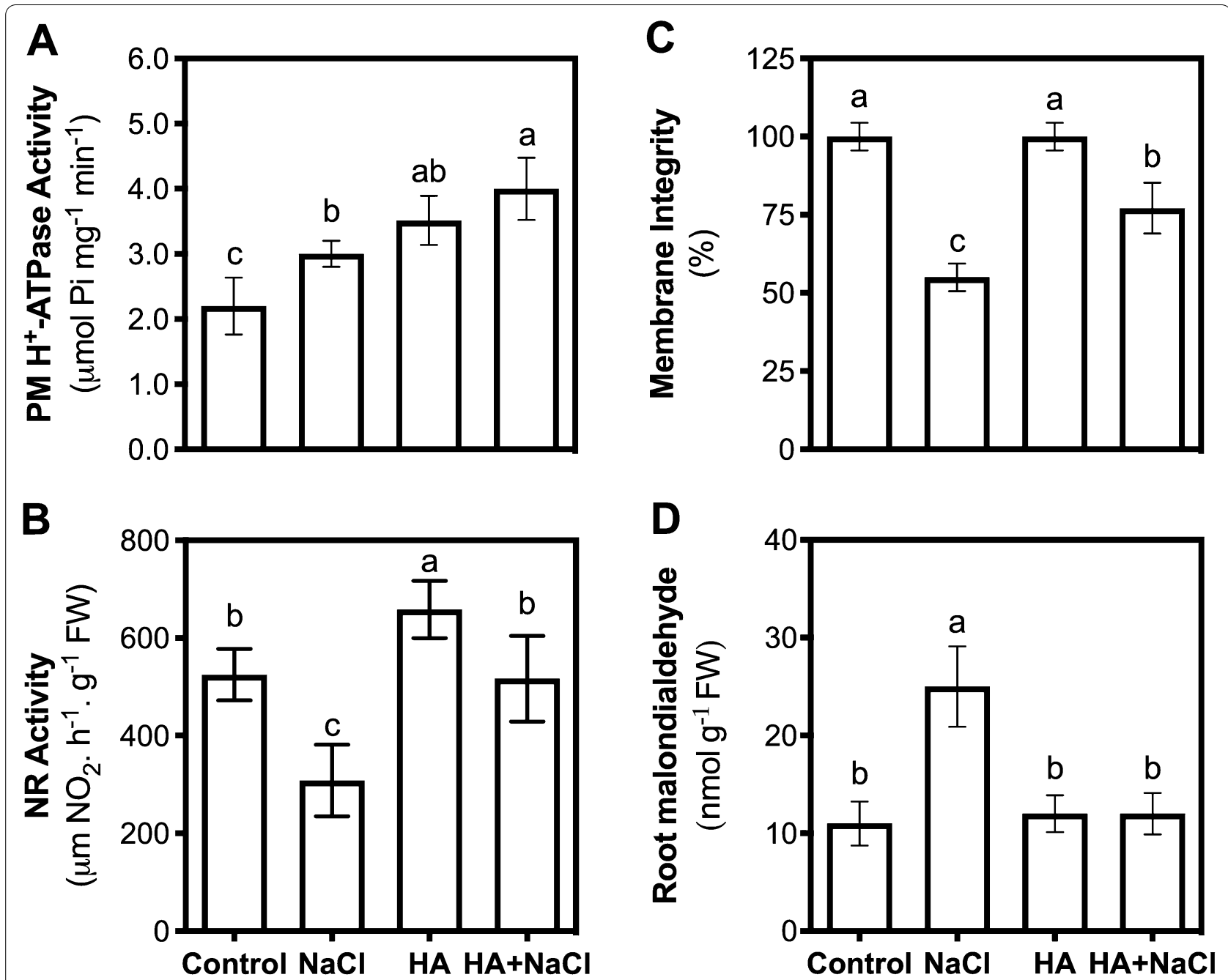

Fig. 7 A Activity of plasma membrane $H^{+}$-ATPase and $\mathbf{B}$ nitrate reductase. $\mathbf{C}$ Root membrane integrity; $\mathbf{D}$ malondialdehyde content. Data were obtained in 5-week-old plants with either control (1/2 strength Hoagland solution) or humic acids (control $+4 \mathrm{mM}$ C HA) further treated for additional 7 days with $300 \mathrm{mM} \mathrm{NaCl}, 4 \mathrm{mM} \mathrm{C} \mathrm{HA} \mathrm{or} 300 \mathrm{mM} \mathrm{NaCl}$ plus $4 \mathrm{mM} \mathrm{C} \mathrm{HA}$. Values are presented as means $\pm S D(n=10)$. Different letters represent average values that were judged to be statistically different between 7 -day treated plants $(P<0.05$, Tukey test)

The role of NAC in the multiple abiotic stress response was highlighted by Shao et al. [24]. NAC plays a pivotal role in converting stress signal perception to stressresponsive gene expression, and humic acids may elicit the SOS3 system that acts as a $\mathrm{Ca}^{2+}$ sensor. Moreover, the SOS system plays a critical role in the plastic development of lateral roots by modulating auxin gradients in roots under mild salt conditions [25]. The stress-inducible NAC genes are involved in abiotic stress tolerance in both dependent and independent ABA signalizations. NAC transcription factor is an important candidate of gene target in the biotechnology tools set up to improve crop stress response [26]. Moreover, despite the unknown interaction of other proteins in Arabidopsis, the ZmbZIP17 transcription factor was described as involved in the crosstalk signalization in response to abiotic stress, including $\mathrm{NaCl}$ stress, mainly in shoot tissues [27]. Besides, we found a large transcription level of ZmbZIP17 (20-fold in respect to control) in root maize seedlings primed by humic acids (Fig. 5).

The auxin-like activity of HA is probably the main biological factor responsible for the positive effects exerted by humic substances on plant physiology [28]. Its effect on NAC transcription can provide the link relating humic acids to root development and salt stress. The NAC1 transcription factor promotes lateral root initiation in Arabidopsis [29] and may bind auxin-responsive promoters to transmit the auxin signal. The NAC1 expression is induced within $30 \mathrm{~min}$ of auxin application, suggesting that NAC1 may be an 
early auxin-responsive gene [29]. Humic acids induced the ZmNAC66 expression by emulating the auxin signal on NAC1 expression. The effect of humic acids on protein kinases is known, since the CDPK expression was induced by humic acids in rice [11]. In addition, it is known that humic acids can disturb the plant nutrient-sensing either indirectly by affecting cell membrane transporters [30] or directly by altering the expression of the target of the rapamycin (TOR) kinase complex [31].

Nutrient sensing is a key to plant adaptation, and TOR kinases play a central role in this process [32]. The SnRK1 kinases are key regulators of plant energy and act not only by inhibiting the growth-stimulating and high energy-activated TOR kinase but also in a TOR independent way, for example, by transcriptional reprogramming partially mediated by the $\mathrm{C} / \mathrm{S} 1$ group bZIP transcription factor network [33]. SnRK1 signalling also crosstalks with abscisic acid (ABA)-induced SnRK2, both upstream through the common regulation by PP2C phosphatases, and, possibly, also downstream by targeting SnRK2-regulated A group bZIP transcription factors [34]. It is possible to indicate that humic acids may absorb or release signalling molecules that prepare seedlings for subsequent salt stress response. The physiological adjustment observed in tomatoes that were first primed by HA (Figs. 6, 7) and then underwent salt stress agrees with the results observed with the maize seedlings assay. Tomatoes primed by humic acids maintained a large photosynthesis rate, proton pumps and NR activity.

The central role of the PM $\mathrm{H}^{+}$-ATPase in ion uptake and plant growth is well known. In fact, this enzyme provides an electrochemical gradient required to energize the ion transport for cell uptake and induce cell growth by a mechanism known as acid growth, in which $\mathrm{H}^{+}$ions act as intermediates between auxin and cell wall loosening [35]. NR activity enhancement is compatible with the nitrogen assimilation demand induced by the carbon supply sustained by the large photosynthesis rate during salt stress in plants primed by humic acids. The protection of photosynthetic machinery induced by humic acids was evident, since the potential quantum yield of PSII $\left(F_{v} / F_{m}\right)$ in primed plants remained large, while a significant decrease was observed in salt-stressed tomato seedlings.

Plant acclimation is an important strategy for crop adaptation that allows internal adjustments within tissues and cells and enables plant metabolism to respond to abiotic and biotic stress. In the context of salinity, it was previously reported that plants increased the ability to tolerate salt stress after being exposed to low level of $\mathrm{NaCl}$, thus suggesting the pivotal role in the physiological process involved in the prevention of $\mathrm{K}^{+}$leakage and $\mathrm{Na}^{+}$ accumulation, and, consequently, in the enhancement of salt tolerance [3].

\section{Conclusion}

We primed seedlings with humic acids to provide a plant acclimation against further salt stress. We also observed the central role in the physiological adjustment, including changes in ion balance and plasma membrane $\mathrm{H}^{+}$pumps activity. For the first time, we reported the occurrence of a large transcription level of abiotic responsive genes that were induced by humic acids, including those involved in a specific salt response gene (SOS) without the presence of significant salinity. In addition, transcription factors and kinases proteins, involved in cell signalization and cell energy status, were found here to be up-regulated in maize seedlings primed by humic acids, thereby showing a new role of humic matter in the cell signalization processes that prepare plants molecular response against salt stress.

\section{Abbreviations}

CP/MAS ${ }^{13} \mathrm{C}$ NMR: Cross-polarization/magic-angle spinning nuclear magnetic resonance of isotope carbon with 13 mass; HA: Humic acids isolated from vermicompost.

\section{Supplementary Information}

The online version contains supplementary material available at https://doi. org/10.1186/s40538-021-00239-2.

Additional file 1: Table S1. Primer sequence of the genes analysed by RT-qPCR. Table S2. Genes related to osmotic stress (drought/salinity) in the acclimation period in a significant differential expression (in respect to control) in maize root seedlings treated with humic acids. Figure S1. CP/ MAS ${ }^{13} \mathrm{C}$ NMR spectrum of humic-like acids $(\mathrm{HA})$ isolated from vermicompost produced with sugarcane filter cake residue. Figure S2. $\mathrm{NaCl}$ stresssignalling pathways and interactions with humic acids. The stress signal is perceived by a salt sensor present at the plasma membrane. The signal is responsible for kinases activation, including ones that participated in SOS pathways. The kinases were correlated to induced pumps/channels and transcription factors expression (NAC and bZIP family). Activation of $\mathrm{Na}^{2+}$ / $\mathrm{H}^{+}$antiporter (SOS1, vacuolar $\mathrm{Na}^{+} / \mathrm{H}^{+}$antiporter (NHX) was correlated to tolerance to salt stress. $\mathrm{Na}^{2+}$ exclusion (to apoplast) or compartmentalizing (vacuole) is powered by electrochemical gradient generated by $\mathrm{H}^{+}$-ATPase or $\mathrm{H}^{+}$-PPase. The proton electrochemical gradient generated by plasma membrane $\mathrm{H}^{+}$-ATPase results in antiporters ions coupling (antiport $\mathrm{K}^{+} / \mathrm{Na}^{+}$). Sodium $\left(\mathrm{Na}^{2+}\right.$ ) can enter the cell through voltage independent nonselective cation channels like HKT, generating membrane depolarization. Both depolarization of membrane and changes in turgor pressure affect kinases pathways, and increased $\mathrm{Ca}^{2+}$ cytoplasmic concentration, resulting in vacuolar two pore channel 1 (TPC1) activation, which in turn also increases cytoplasmic $\mathrm{Ca}^{2+}$. High cytosolic $\mathrm{Ca}^{2+}$ activates, among others calcium-binding, calmodulin (CDKs), and was also related to HKT activation. Cytosolic $\mathrm{Ca}^{2+}$ signal is sensed by an SnRK3/ calcineurin B-like (CBL) calcium-binding protein complex (SOS3/SOS2) which activates SOS1. Humic acids (HA) increased cytosolic $\mathrm{Ca}^{2+}$, proton pumps, and transcription factors related salt stress responses, such as bZIP and NAC. NAC transcription factor is associated to auxin pathway. SnRK1 regulates carbon metabolism by direct phosphorylation or redox activation or inactivation of metabolic enzymes like nitrate reductase (NR). The SnRK1 activated SnRK2 by Abscisic acid (ABA)-dependent signalling 
pathways which, in turn, activates AREBPs inducing gene expression Abscisic acid can also induce SOS3. Enzymes or transcripts evaluated in this work are in cyan.

\section{Acknowledgements}

Not applicable.

\section{Authors' contributions}

$L P C$, FLO and AP were responsible for the experimental idea. ACS carried out the experiments with maize and done the RT-PCR analysis while DBZ and MPS with tomato. NOAC was responsible for data analysis. CPS and IES da S did the transcription analysis. CER was responsible for the ionic balance. RS did the humic acids characterization. All authors read and approved the final manuscript.

\section{Funding}

This work was supported by Fundação Carlos Chagas Filho de Amparo à Pesquisa do Estado do Rio de Janeiro (FAPERJ) Cientista do Nosso Estado programm, Conselho Nacional de Desenvolvimento de Pesquisa e Tecnologia (CNPq) and FINEP-Pluricana Project. NOAC has received a Post-Doc fellowship from FAPERJ Nota10 program and ACS a Master Degree fellowship from CAPES.

\section{Availability of data and materials}

Not applicable.

\section{Declarations}

\section{Ethics approval and consent to participate}

This manuscript is an original paper and has not been published in other journals. The authors agreed to keep the copyright rule.

\section{Consent for publication}

The authors agreed to the publication of the manuscript in this journal.

\section{Competing interests}

The authors declare that they have no competing interests.

\section{Author details}

${ }^{1}$ Núcleo de Desenvolvimento de Insumos Biológicos Para Agricultura (NUDIBA), UENF-Universidade Estadual Do Norte Fluminense Darcy Ribeiro, Av. Alberto Lamego 2000, Campos dos Goytacazes, Rio de Janeiro 28013-602, Brazil. ${ }^{2}$ Instituto de Biodiversidade E Sustentabilidade, UFRJ-Universidade Federal Do Rio de Janeiro, Macaé, Rio de Janeiro 27965-045, Brazil. ' ${ }^{3}$ UENF-Laboratório de Ciências Ambientais (LCA), Av. Alberto Lamego 2000, Campos dos Goytacazes, Rio de Janeiro 28013-602, Brazil. ${ }^{4}$ Centro Interdipartimentale Per La Risonanza Magnetica Nucleare (CERMANU), Università Di Napoli Federico II, Via Università 100, 80055 Portici, Italy.

Received: 19 October 2020 Accepted: 2 July 2021

Published online: 04 August 2021

\section{References}

1. Wang W, Vinocur B, Altman A. Plant responses to drought, salinity and extreme temperatures: towards genetic engineering for stress tolerance. Planta. 2003;218:1-14.

2. Munns R, Tester M. Mechanisms of salinity tolerance. Ann Rev Plant Biol. 2008;59:651-81.

3. Pandolfi C, Mancuso S, Shabala S. Physiology of acclimation to salinity stress in pea (Pisum sativum). Environ Exp Bot. 2012;84:44-51.

4. Berbara RLL, García AC. Humic substances and plant defense metabolism. In: Ahmad P, Wani MR, editors. Physiological mechanisms and adaptation strategies in plants under changing environment. New York: Springer; 2014. p. 297-319.
5. Van Oosten MJ, Pepe O, De Pascale S, Silletti S, Maggio A. The role of biostimulants and bioeffectors as alleviators of abiotic stress in crop plants. Chem Biol Technol Agric. 2017;4:5.

6. Shah ZH, Rehman HM, Akhtar T, Alsamadany H, Hamooh BT, Mujtaba T, Daur I, Al Zahrani Y, Alzahrani HAS, Ali S, Yang SH, Chung G. Humic substances: determining potential molecular regulatory processes in plants. Front Plant Sci. 2018;9:263.

7. du Jardin P. Plant biostimulants: definition, concept, main categories and regulation. Sci Hort. 2015;196:3-14.

8. García AC, Santos LA, Guridi-Izquierdo F, Rumjanek VM, Castro RN, Santos FS, de Souza LGA, Berbara RLL. Potentialities of vermicompost humic acids to alleviate water stress in rice plants (Oryza sativa L.). J Geochem Explor. 2014;136:48-54.

9. Canellas LP, Canellas NOA, da Irineu LESS, Olivares FL, Piccolo A. Plant chemical priming by humic acids. Chem Biol Technol Agric. 2020;7:12

10. Nardi S, Carletti P, Pizzeghello D, Muscolo A. Biological activities of humic substances. In: Senesi N, Xing B, Huang PM, editors. Biophysicochemical processes involving natural non-living organic matter in environmental systems, vol. 2. 1st ed. Hoboken: Wiley; 2009. p. 305-40.

11. Ramos AC, Olivares FL, Silva LS, Aguiar NO, Canellas LP. Humic matter elicits proton and calcium fluxes and signaling dependent on $\mathrm{Ca}^{2+}$-dependent protein kinase (CDPK) at early stages of lateral plant root development. Chem Biol Technol Agric. 2015;1:1-12.

12. Azevedo IG, Olivares FLO, Ramos ACR, Bertolazi AA, Canellas LP. Humic acids and Herbaspirillum seropedicae change the extracellular $\mathrm{H}^{+}$ flux and gene expression in maize roots seedlings. Chem Biol Technol Agric. 2019;6:8

13. Khaleda L, Park HJ, Yun DJ, Jeon JR, Kim MG, Cha JY, Kim WY. Humic acid confers high-affinity $\mathrm{K}^{+}$transporter 1-mediated salinity stress tolerance in Arabidopsis. Mol Cells. 2017;40(12):966-75.

14. Hellemans J, Mortier G, De Paepe A, Speleman F, Vandesompele J. qBase relative quantification framework and software for management and automated analysis of real-time quantitative PCR data. Genome Biol. 2007;8:19. https://doi.org/10.1186/gb-2007-8-2-r19.

15. Duarte HM, Geßler A, Scarano FR, de Mattos EA, Nahm M, Rennenberg H, Rodrigues PJFP, Zaluar HLT, Lüttge U. Ecophysiology of six selected shrub species in different plant communities at the periphery of the Atlantic Forest of SE-Brazil. Flora Morphol Distrib Funct Ecol Plants. 2005;200:456-76

16. Wellburn AR. The spectral determination of chlorophylls a and b, as well as total carotenoids, using various solvents with spectrophotometers of different resolution. J Plant Physiol. 1994;144:307-13.

17. Canellas LP, Olivares FL, Okorokova-Façanha AL, Façanha AR. Humic acids isolated from earthworm compost enhance root elongation, lateral root emergence, and plasma membrane $\mathrm{H}^{+}$-ATPase activity in maize roots. Plant Physiol. 2002;130:1951-9.

18. Santos MP, Zandonadi DB, de Sá AFL, Costa EP, de Oliveira CJL, Perez $L E$, Bressan-Smith R. Abscisic acid-nitric oxide and auxin interaction modulates salt stress response in tomato roots. Theor Exp Plant Physiol. 2020;32(4):301-13.

19. Spaccini R, Sannino D, Piccolo A, Fagnano M. Molecular changes in organic matter of a compost-amended soil. Eur J Soil Sci. 2009:60:287-96.

20. Zandonadi DB, Canellas LP, Façanha AR. Indolacetic and humic acids induce lateral root development through a concerted plasmalemma and tonoplast $\mathrm{H}^{+}$pumps activation. Planta. 2007;225:1583-95.

21. Ishitani M, Liu J, Halfter U, Kim C-S, Shi W, Zhu J-K. SOS3 function in plant salt tolerance requires $\mathrm{N}$-myristoylation and calcium binding. Plant Cell. 2000;12:1667.

22. Almeida DM, Oliveira MM, Saibo NJM. Regulation of $\mathrm{Na}^{+}$and $\mathrm{K}^{+}$ homeostasis in plants: towards improved salt stress tolerance in crop plants. Gen Mol Biol. 2017:40:326-45.

23. Halford Nigel G, Hey SJ. Snf1-related protein kinases (SnRKs) act within an intricate network that links metabolic and stress signalling in plants. Biochem J. 2009:419:247-59.

24. Baena-González E, Rolland F, Thevelein JM, Sheen J. A central integrator of transcription networks in plant stress and energy signalling. Nature. 2007:448:938-42.

25. Shao H, Wang H, Tang X. NAC transcription factors in plant multiple abiotic stress responses: progress and prospects. Front Plant Sci. 2015;6:902. 
26. Ji H, Pardo JM, Batelli G, Van Oosten MJ, Bressan RA, Li X. The salt overly sensitive (SOS) pathway: established and emerging roles. Mol Plant. 2003;6:275-86

27. Nakashima K, Takasaki H, Mizoi J, Shinozaki K, Yamaguchi-Shinozaki K. NAC transcription factors in plant abiotic stress responses. Biochim Biophys Acta Gene Regul Mech. 2012;1819:97-103.

28. Jia Z, Lian Y, Zhu Y, He J, Cao Z, Wang G. Cloning and characterization of a putative transcription factor induced by abiotic stress in Zea mays. Afr J Biotechnol. 2009;8:24

29. Nardi S, Pizzeghello D, Ertani A. Hormone-like activity of the soil organic matter. Appl Soil Ecol. 2018;123:517-20.

30. Jindo K, Mazzei PL, Olivares FL, Piccolo A, Canellas LP. Phosphorus speciation and high-affinity transporters are influenced by humic substances. J Plant Nutr Soil Sci. 2016;179:206-214

31. Xie Q, Frugis G, Colgan D, Chua N-H. Arabidopsis NAC1 transduces auxin signal downstream of TIR1 to promote lateral root development. Genes Develop. 2000;14:3024-36.
32. Canellas LP, Canellas NOA, Soares TS, Olivares FL. Humic acids interfere with nutrient sensing in plants owing to the differential expression of TOR. J Plant Growth Reg. 2019;38:216-24.

33. Robaglia C, Thomas M, Meyer C. Sensing nutrient and energy status by SnRK1 and TOR kinases. Curr Op Plant Biol. 2012;15:301-7.

34. Crepin N, Rolland F. SnRK1 activation, signaling, and networking for energy homeostasis. Curr Op Plant Biol. 2019;51:29-36.

35. Morsomme P, Boutry M. The plant plasma membrane $\mathrm{H}^{+}$-ATPase: structure, function and regulation. Biochim Biophys Acta Biomembr. 2000;1465:1-16.

\section{Publisher's Note}

Springer Nature remains neutral with regard to jurisdictional claims in published maps and institutional affiliations.

\section{Submit your manuscript to a SpringerOpen ${ }^{\circ}$ journal and benefit from:}

- Convenient online submission

- Rigorous peer review

- Open access: articles freely available online

- High visibility within the field

- Retaining the copyright to your article

Submit your next manuscript at springeropen.com 